\title{
BLOOD VISCOSITY AND THE OVERNIGHT FAST
}

\author{
H. B. Aronson, Tifha Horne, S.H. Blondheim and J. T. Davidson
}

ABStract

\begin{abstract}
A 12-hour overnight fast in 17 subjects did not result in a significant increase in blood viscosity, as occurs after a 24-hour fast. The usual preoperative fast does not therefore appear to have any adverse rheological effect. However, when it is necessary to prolong the fast, intravenous fluids should be given to prevent the expected increase in blood viscosity which then might have clinical effects as a result of decreased organ perfusion.
\end{abstract}

\section{INTRODUCTION}

SAFETY IN ELECTIVE ANAESTHESIA demands complete abstinence from both food and drink for a minimum of 6 hours to avoid aspiration of stomach contents, one of the grave complications of anaesthesia. However, delays in the operating schedule often result in patients being inadvertently subjected to fasting for much longer than the usual 10-12-hour overnight period. Recently we reported ${ }^{1}$ that blood viscosity and haematocrit increased significantly in subjects who refrained from food and drink for 24 hours. This could reduce blood flow to vital organs ${ }^{2-5}$ by increasing peripheral resistance and reducing cardiac output. Therefore fasting, depending on duration, might have deleterious clinical effects. The purpose of this study was to determine whether a 12-hour overnight fast also increases blood viscosity and haematocrit.

\section{Materials and Methods}

Seventeen volunteers, 13 of them male, aged 18 to 63 ycars, were investigated. Blood was sampled in the evening before supper (after the usual breakfast and lunch) and again at $7 \mathrm{a} . \mathrm{m}$. after an overnight fast of 12 hours. Seven $\mathrm{ml}$ was drawn with a minimum of venous compression and transferred into glass tubes containing a dried mixture of two per cent potassium oxalate and three per cent ammonium oxalate. After gentle mixing, the samples were placed in cracked ice

H.B. Aronson, M.B., Ch.B., D.A., F.F.A.R.C.S.(I), Department of Anaesthesia, Hadassah-University Hospital, Mount Scopus, Jerusalem, Israel. Tifha Horne, M.D., and S.H. Blondheim, M.D. B.S. Metabolic Laboratory and the Department of Medicine B, Hadassah-University Hospital, Ein Karem, Jerusalem, Israel. J.T. Davidson, L.R.C.P. \& S., D.A., F.F.A.R.C.S., Department of Anaesthesia, Hadassah-University Hospital, Ein Karem, Jerusalem, Israel. and transferred to the laboratory where the following investigations were done:

Blood viscosity was determined in duplicate at five shear rates $\left(230,115,46,23\right.$ and $\left.11.5 \operatorname{secs}^{-1}\right)$, in a cone-plate microviscometer (Brookfield LVT $\left.^{*}\right)^{6}$ thermostatically controlled at $37^{\circ} \mathrm{C}$.

Haematocrit was measured after spinning in an Adams Autocrit centrifuge at $12,000 \mathrm{~g}$ for five minutes.

\section{RESULTS}

At all except one of the five shear rates studied (23 secs $^{-1}$ ) the blood viscosity was higher after the overnight fast than before. However, none of these increases were statistically significant (Table I).

Mean haematocrit increased by 3.2 per cent during the overnight fast, from $44.1 \pm 4.0$ (S.D.) to $45.5 \pm 3.2$ per cent, an increase of minimal significance $(p<0.05,1$-tailed test) (Table I).

\section{Discussion}

The results indicate that after a 12 -hour overnight fast there is no significant increase in blood viscosity compared with the control values obtained when subjects are not fasting. The routine overnight fast before elective surgery should therefore not be rheologically harmful. Nevertheless, as a result of fasting, there was a slight but definite haemoconcentration as expressed by a small statistically significant increase in haematocrit. This degree of haemoconcentration apparently was not sufficient to produce a significant increase in blood viscosity. On the other hand, we have shown that blood viscosity did increase by a statistically significant 16.5 per cent as a result of a 24-hour fast." Therefore, prolongation of the "nil per mouth" order for patients whose operation is delayed for more than 12 hours could bring them into the range when

"Brookfield Engineering Co., Stoughton, Mass. 


\section{TABLE I}

EfFect of a 12-Hour Overnight Fast on Blood Viscosity and Haematocrit (means \pm S.D. of 17 subjects)

\begin{tabular}{|c|c|c|c|c|c|c|}
\hline & \multicolumn{5}{|c|}{ Blood viscosity (centipoises) } & \multirow{3}{*}{$\begin{array}{c}\text { Haematocri } \\
\text { per cent }\end{array}$} \\
\hline & \multicolumn{5}{|c|}{ Shear rate $\left(\mathrm{sec}^{-1}\right)$} & \\
\hline & 220 & 115 & 46 & 23 & 11.5 & \\
\hline $\begin{array}{l}\text { Control } \\
\text { (evening) }\end{array}$ & $\begin{array}{r}4.33 \\
+0.51\end{array}$ & $\begin{array}{r}4.75 \\
+0.43\end{array}$ & $\begin{array}{r}5.49 \\
\pm 0.58\end{array}$ & $\begin{array}{r}7.23 \\
\pm 0.79\end{array}$ & $\begin{array}{r}9.62 \\
\pm 0.32\end{array}$ & $\begin{array}{r}44.1 \\
\pm 4.0\end{array}$ \\
\hline $\begin{array}{l}\text { Fasting } \\
\text { (morning) }\end{array}$ & $\begin{array}{r}4.75 \\
\pm 0.55\end{array}$ & $\begin{array}{r}4.78 \\
\pm 0.48\end{array}$ & $\begin{array}{r}5.77 \\
\pm 0.62\end{array}$ & $\begin{array}{r}7.08 \\
+0.79\end{array}$ & $\begin{array}{r}9.72 \\
\pm 1.38\end{array}$ & $\begin{array}{r}45.5 \\
\pm 3.2\end{array}$ \\
\hline $\begin{array}{c}\text { Percentage } \\
\text { change }\end{array}$ & +9.7 & +3.0 & +5.1 & -2.1 & +1.0 & +3.2 \\
\hline$p^{*}$ & n.s. & n.s. & n.s. & n.s. & n.s. & 0.05 \\
\hline
\end{tabular}

*probability; Student's t-test for paired observations (1-tailed test of increase).

increased haemoconcentration, among other factors, would be expected to increase blood viscosity. This is likely to be of clinical importance, particularly in aged, ill or polycythaemic patients in whom the increase in blood viscosity could further reduce the blood flow to, and therefore the perfusion of vital organs. ${ }^{7}$.

Increased blood viscosity may contribute to the impairment of myocardial function and oxygen utilization that occurs with increases in free fatty acids, another effect of fasting. ${ }^{8,9}$ It might also be related to the tendency to arrhythmia noted in fasting rats anaesthetized with either halothane or diethyl ether, ${ }^{10}$ and/or to the inhibition of renal function and the depletion of liver glycogen stores ${ }^{11.12}$ reported during prolonged fasting. It is not unreasonable to suggest, therefore, that the depression of kidney and liver function induced by general anaesthesia ${ }^{13-15}$ might be accentuated by prolongation of the preoperative fast.

We conclude that, while an overnight fast of the usual duration does not increase blood viscosity significantly, prolongation of the fast for more than 12 hours may very well do so. Therefore, when the preoperative period is lengthy, supplementary fluids should be given, particularly to older patients and others with relatively high haematocrit values.

\section{REFERENCES}

1. Aronson, H.B., Horne, T., Blondheim, S.H., DAvidson, J.T. \& Blondheim, D.S. Effect of a 24-hour fast on blood and plasma viscosity. Israel Journal of Medical Sciences 10: 833 (1979).

2. Thomas, D.J., du Boulay, G.H. Marshall, J, Pearson, T.C., Ross Russell, R.W., Symon, L., Wetherley-MejN, G. \& Zilkha, E. Effect of haematocrit on cerebral blood-flow in man. Lancet. Nov. 5: 941 (1977).

3. Messmer, K., Sunder-Plassman, L., KloveKORN, W.P. \& HOLPER, K. Circulatory significance of hemodilution; rheological changes and limitations. Advances in Microcirculation. 4: 1 (1972).

4. Dormandy, J.A. Clinical Significance of blood viscosity. Proceedings of the Royal Society of Medicine. 47: 211 (1970).

5. Barry, K.G., Mazze, R.1. \& Schwartz, F.D Prevention of surgical oliguria and renalhemodynamic suppression of sustained hydration. New England Journal of Medicine. 270: 1371 (1964).

6. Wells, R.E. JNR., Denton, R. \& Merrill, E.W. Measurement of viscosity of biologic fluids by cone-plate viscometer. Journal of Laboratory Clinical Medicine. 57: 646 (1961).

7. WELLS, R.E. JNR. Rheology of blood in the microvasculature. New England Journal of Medicine. 270: 832, 839 (1964).

8. Muos, D. Effect of free fatty acids on myocardial function and oxygen consumption in intact dogs. Journal of Clinical Investigation. 50: 1386 (1971).

9. CAHILl, G.F. Starvation in man. New England Journal of Medicine. 282: 668 (1970).

10. Miletich, D.J., Aldrecht, R.F. \& Seals, C. Responses to fasting and lipid infusion of epinephrine-induced arrhy thmias during halothane anaesthesia. Anesthesiology 48: 245 (1978).

11. Merin, R.G. New implications of fasting. Anesthesiology 48: 236 (1978).

12. BRUCE, D.L. Anesthetic implications of fasting. Anesthesia Analgesia 50:612 (1971).

13. Mazze, R.1., Schwartz. R.D., Slocum, H.C. \& KEVIN, G.B. Renal function during anesthesia and surgery. Anesthesiology 4: 279 (1963).

14. Shackmanm, R., Graber, I.G. \& Melrose, D.G. Liver blood flow and general anesthesia. Clinical Science 12: 307 (1953).

15. Cowan, R. E., Jackson, B.T. \& Thompson, R.P.H. The effects of various anaesthetics and abdominal surgery on liver blood flow in man. Gut. 16: $839(1975)$. 


\section{RÉSUMÉ}

Un jeûne nocturne, d'une durée de 12 heures, imposé à 17 jeunes sujets en bonne santé, $n$ 'a pas provoqué d'accroissement significatif de la viscosité sanguine, contrairement à ce que l'on obșerve lorsque le jeûne dure 24 heures; on en conclut donc que le jeûne pré-opératoire habituel n'induit probablement pas d'effet rhéologique défavorable. Cependant, lorsque le jeûne est appelé à se prolonger au-delà d'une douzaine d'heures, il devient nécessaire d'administrer des liquides par voie veineuse pour prévenir l'augmentation de la viscosité sanguine qui pourrait avoir des effets néfastes sur la perfusion tissulaire. 